Article

\title{
Social Exclusion and Mental Wellbeing in Older Romanians
}

\author{
Iuliana Precupetu ${ }^{1, *}$, Marja Aartsen ${ }^{2}$ and Marian Vasile ${ }^{3}$ \\ ${ }^{1}$ Research Institute for Quality of Life, Romanian Academy, 050711 Bucharest, Romania; E-Mail: iuliana@iccv.ro \\ 2 NOVA Norwegian Social Research, OsloMet-Oslo Metropolitan University, 0170 Oslo, Norway; \\ E-Mail: maraar@oslomet.no \\ ${ }^{3}$ Faculty of Sociology and Social Work, University of Bucharest, 010181 Bucharest, Romania; \\ E-Mail: marian.vasile@sas.unibuc.ro \\ * Corresponding author
}

Submitted: 5 February 2019 | Accepted: 4 April 2019 | Published: 29 July 2019

\begin{abstract}
In Romania, inequalities in health and wellbeing between younger and older Romanians are substantial, and an important reason for inequalities may be the higher risk of social exclusion among older adults. After the fall of Communism in 1989, the many transformations in economic structures and welfare regimes contributed to enhanced levels of social exclusion, in particular among the older generations. Social exclusion is a multidimensional problem with substantial effects on the mental wellbeing of people. The present study examines age differences in mental wellbeing and evaluates to what extent differences can be explained by age and social exclusion, while controlling for a number of potential confounders. Data are from the fourth wave (2016) of the European Quality of Life Survey. Data for Romania include 1004 people aged between 18 and 85 years old, of which 726 are included in the analyses (only complete cases). In the study sample, 259 were 55 years or older. Mental wellbeing was measured with The World Health Organization Wellbeing Index (WHO-5 scale), and social exclusion was measured in four domains: social relations, material resources, services and the neighbourhood. The results show that older Romanians have a statistically significant lower mental wellbeing than younger generations in Romania. All domains of social exclusion were associated with lower levels of mental wellbeing. These effects remained statistically significant after controlling for partner status, chronic diseases, having children, and level of education. Improving mental wellbeing of older Romanians would greatly benefit from increasing social inclusion by means of social transfers provided by the government, improving the neighbourhood and access to services, and providing facilities to enhance the social network.
\end{abstract}

\section{Keywords}

ageing; mental wellbeing; post-Communist welfare; social exclusion; Romania

\section{Issue}

This article is part of the issue "Old-Age Exclusion", edited by Wouter De Tavernier (KU Leuven, Belgium) and Marja Aartsen (OsloMet-Oslo Metropolitan University, Norway).

(C) 2019 by the authors; licensee Cogitatio (Lisbon, Portugal). This article is licensed under a Creative Commons Attribution 4.0 International License (CC BY).

\section{Introduction}

In Romania, there are large inequalities in health and wellbeing between younger and older generations. After the fall of the Communist regime, many transformations in the economic structures, labour markets, political institutions, and welfare regimes took place, which impacted heavily on the standards of living of all Romanians, but the older generations in particular. The accumulation of factors associated with age, such as poor health, loss of relatives and friends, and lower physical and social activities, may have contributed to a trend of increasing social and economic inequalities with strong effects on feelings of uncertainty, vulnerability, and deprivation.

Starting in 1990, Romania made a slow and painful dual transition to a market economy and democratic sys- 
tem, characterised by high social costs (Sandu, 1999; World Bank, 2018; Zamfir, 2007). The poor Communist institutional legacies, coupled with a hesitant approach to economic and social reforms, led to an important economic decline and a large increase in poverty in the first phase of transition (Hellman, 1998; World Bank, 2008). This has affected the oldest cohorts in particular. The GINI coefficient ${ }^{1}$ - reflecting income inequalityincreased from 22.2 in 1990 to 33.7 in 2007. This placed Romania at the top of the EU countries with the highest levels of inequality (United Nations University, 2018). Even though income inequality lessened in the past decade to a certain extent, with a Gini value of 33.1, the country still ranks among the highest in the EU with regards to income inequality (Eurostat, 2017), and a wide range of deeply entrenched social disparities persist between young and old people (Precupetu \& Precupetu, 2014).

Of all transitions that took place after the fall of Communism, the economic transition probably had the strongest consequences for older people, as it excluded them from mainstream society and turned them into "the losers of the transition" (Mărginean, 2006, p. 65). During the Communist regime, there was universal social protection through employment for all, but there was also a strong expectation that people should retire from their working lives and participate much less in society while benefiting from their hard-earned pensions. Remaining active in the labour market was only possible for a few categories, such as those working in agricultural cooperatives, in the social economy or, for those owning plots of land, in subsistence agriculture. Other forms of social participation were also severely limited after retirement as there was no civil society and the only forms of involvement were at the community level, in narrow family and neighbourhood networks. The Communist regime never prioritised the social protection and quality of life of retired people (Petrescu, 2019). Care responsibilities were considered a family duty as only a limited supply of public "elderly homes" would provide services to a small number of older people (Petrescu, 2019). Over the transition period, due to early retirement schemes, the older cohorts went into retirement at a younger age than the later born cohorts who reached retirement age. Employment rates of older people registered a significant drop, especially in the period of rapid privatisation in the economy. Employees in the older age groups have not been sufficiently able to adapt to the new challenges of the market economy (Zaman \& Stănculescu, 2007). Many older people got involved in subsistence agriculture on small plots of land or went into the informal economy. The intricate context of transition thus impacted more heavily on older people than younger cohorts as their opportunities narrowed considerably.

Older Romanians are disadvantaged in many respects. They have a low standard of living, low access to health services, poor access to, and low quality of social services, low social participation, low quality of housing, and low quality of public services (Bodogai \& Cutler, 2014; Eurofound, 2017; Petrescu, 2019). Probably as a consequence, older adults in Romania are among those with the lowest levels of mental wellbeing in Europe (Eurofound, 2016a; Mărginean, 2006; Sandu, 2009). When the disadvantage is severe and pertains to more domains, it will result in a number of negative consequences for the wellbeing of older adults (Levitas et al., 2007). However, empirical evidence supporting this claim for older Romanians is lacking, as gerontological research in Romania is sparse and mainly descriptive. Studies have so far looked at demographic changes (Bălașa, 2005; Neményi, 2011), older people's needs and effective ways of intervention (Gîrleanu-Şoitu, 2006), social assistance, and pensions (Mărginean, 2015). A few qualitative studies have concentrated on Romania and highlighted the predominantly negative views of ageing (Craciun, 2011) or patterns of social capital of older persons (Craciun, 2012). The present study aims to narrow the knowledge gap by examining associations between various dimensions of social exclusion and mental wellbeing in older Romanians.

One concept that may be helpful to understand the multidimensional disadvantages of older Romanians is social exclusion. There are extended scientific and political debates about what social exclusion is. Whereas the European Union defines social exclusion primarily in terms of poverty, material deprivation, and exclusion from the labour market, social scientists argue that it is much more than that. Theories about social exclusion argue that it is a complex and multidimensional phenomenon with substantial disruptive health and wellbeing consequences for individuals and society (Walsh, Scharf, \& Keating, 2017). Social exclusion involves many domains, among which exclusion from social relations, exclusion from economic resources, exclusion from health and social services, and exclusion from participation in civic society (Walsh et al., 2017). Exclusion from one domain often enhances exclusion from other domains. For example, a lack of financial resources reduces possibilities for (new) social relations, which in turn make people more dependent on public services, such as health services, social institutions, and public transportation. If access to these services is insufficient, it will reduce opportunities for civic participation and lead to substantial mental and physical health problems. If, in addition, the access to the domains is unequal for different social groups (i.e., men and women, older and younger people) the process of social exclusion will lead to large inequalities in health (O'Donnell, O'Donovan, \& Elmusharaf, 2018). The process of social exclusion in older people occurs as they age, and older people have an increased risk of social exclusion due to the accumulation of factors associated with age, such as poor health,

\footnotetext{
${ }^{1}$ The TransMonEE data refer to the distribution of the population by per capita household net income and the Eurostat measure is the Gini coefficient of equivalised disposable income using the modified OECD scale.
} 
loss of relatives and friends, and fewer physical and social activities.

In our study, we acknowledge the multidimensional nature of social exclusion by using the multiple domains in which exclusion may occur as defined in the study by Walsh et al. (2017), i.e., social relations, civic participation, health and social services, material and financial resources, socio-cultural aspects, and neighbourhood and community. In line with the theory, we assume that the domains of social exclusion are interrelated, and that exclusion from one domain enhances exclusion in other domains. Research that takes the multiple aspects of social exclusion into account, therefore, provides a more holistic and realistic picture of the relation between social exclusion and wellbeing.

Empirical evidence for associations between various domains of social exclusion and wellbeing comes from a number of studies. Exclusion from social relations may enhance feelings of loneliness and lead to a lack of social support, which are well-known risk factors for lowered levels of wellbeing (Holt-Lunstad, Smith, Baker, Harris, \& Stephenson, 2015; Ong, Uchino, \& Wethington, 2016; Prince, Harwood, Blizard, Thomas, \& Mann, 1997). Loneliness is associated with a range of adverse health outcomes among which increased morbidity, more depressive symptomatology, reduced physical health, impaired daytime functioning, reduced physical activity, and lower subjective wellbeing (Ong et al., 2016). Lack of social support increases the risk of premature mortality in older men and women (Holt-Lunstad et al., 2015).

Exclusion from material and financial resources is strongly related to wellbeing in later life. Effects may be stronger when experienced over longer periods, despite some evidence that older adults can adapt to a lower level of financial resources (Clark, D'Ambrosio, \& Ghislandi, 2015). Material disadvantage tends to accumulate over the life course through socio-economic correlates and life events (Price, 2006). There is also substantial evidence that lack of material and financial resources is associated with increased levels of frailty and poor health among older adults (Mackenbach et al., 2018; Stolz, Mayerl, Waxenegger, \& Freidl, 2017). Exclusion from services involves areas such as health and social care, new technologies, transport, and mobility. This type of exclusion was found to explain variance in the wellbeing of older people living in both urban and rural areas, being more important in urban (Dahlberg \& McKee, 2018). The neighbourhood and community are also relevant domains for social exclusion. Some even call it the most effective area in which to enhance links between people and re-engage individuals (Moulaert, Wanka, \& Drilling, 2017). Research suggests that important aspects of the neighbourhood and community are the built environment, socio-political structures, and fear of crime (Walsh et al., 2017), and some studies found that neighbourhood exclusion was associated with the poor wellbeing of older people, especially in rural communities (Dahlberg \& McKee, 2018). However, research on associations between neighbourhoods and social exclusion has only recently started in the UK, focusing mainly on how neighbourhoods influence social exclusion (Scharf, Phillipson, \& Smith, 2005). When considered as a multidimensional phenomenon, social exclusion was found to be related to significant drops in quality of life in areas like optimism, life satisfaction, disposition, and energy (Barnes, Blom, Cox, Lessof, \& Walker, 2006; Scharf et al., 2005). Two other domains (civic participation and socio-cultural aspects) could not be included because of a lack of information in the dataset (see section on methods).

This study seeks to examine associations between the distinguished domains of social exclusion and mental wellbeing. Mental wellbeing involves "good psychological functioning" (OECD, 2013, p. 10), "a state in which every individual realises his or her own potential, can cope with the normal stresses of life, can work productively and fruitfully, and is able to make a contribution to her or his community" (WHO, 2004). The main research question that we seek to answer in this article is whether the lower level of mental wellbeing in older Romanians compared to younger Romanians can be understood in terms of a greater likelihood of being socially excluded. Disadvantages in the past may have accumulated over the years (Dannefer, 2003) such that the largest inequalities can be observed between younger and older age groups (Eurofound, 2016a; Mărginean, 2006; Sandu, 2009). Based on the theoretical perspectives and empirical evidence described above, we hypothesise that when compared to younger Romanians, older Romanians have lower levels of mental wellbeing (H1) which can be explained by their higher levels of social exclusion $(\mathrm{H} 2)$.

\section{Methods}

\subsection{Data}

Data come from the European Quality of Life Survey (EQLS), a pan-European survey focused on the quality of life, carried out by the European Foundation for the Improvement of Living and Working Conditions (2018). EQLS includes indicators on employment, income, education, housing, family, health, work-life balance, as well as on the subjective wellbeing and quality of society. We make use of the fourth EQLS-wave conducted in 2016, including nationally representative samples in 28 member states and five candidate countries (Albania, FYR Macedonia, Montenegro, Serbia and Turkey). The original Romanian sample included 1004 people aged 18 to 85. After excluding cases with missing data, multiple linear regressions (method enter) were conducted for the 726 remaining complete cases of which 259 were 55 years or older. The data were weighted according to recommendations of the technical report of the EQLS (Eurofound, 2016b) by using the appropriate weight for analysis at the country level and below the country level. 


\subsection{Dependent Variable}

The dependent variable "mental wellbeing" is assessed with the World Health Organization Wellbeing Index (WHO-5 scale). The scale consists of five items: 1. "I have felt cheerful and in good spirits", 2. "I have felt calm and relaxed", 3. "I have felt active and vigorous", 4. "I woke up feeling fresh and rested" and 5. "My daily life has been filled with things that interest me".

Each respondent is asked to rate how well each of the five statements applies to him or her when considering the last 14 days. Each item is scored from 1 (all of the time) to 6 (none of the time). The WHO- 5 scale has adequate validity both as a screening tool for depression and as an outcome measure in clinical trials and can be used to assess wellbeing over time and to compare wellbeing between groups (Topp, Østergaard, Søndergaard, \& Bech, 2015). In accord with Topp et al. (2015) and research reports by Eurofound (2017), we reversed the response scale for each item such that higher scores indicate better wellbeing. We computed factor scores for the recoded scale given their advantages over the summative score, despite the fact that this may have capitalised sampling variability (Treiman, 2009, p. 250). Factor scores were computed as regression scores in SPSS 23 using FACTOR command, PRINCIPAL AXIS FACTORING method, and VARIMAX rotation.

\subsection{Independent Variables}

Age was recorded in years and dichotomised into people aged 55 years and older (1), and people younger than 55 (0). The age threshold was set at 55 in order to attain a satisfactory sample size while maintaining a relevant age category. The rather low threshold for older people is appropriate for populations with lower life expectancy and poor health status. Romanian population has one of the lowest life expectancies in Europe at 75.1 years and a rather problematic health status (Precupetu \& Pop, 2016). Figure 1 presents the age distribution in the sample. We included various indicators of social exclusion identified by Walsh et al. (2017) as the second set of independent variables: material and financial resources, social relations, neighbourhood and community, and services.

Two other domains that Walsh et al. (2017) distinguished could not be included as there was no information about it in the dataset (socio-cultural dimension), or there were only a small number of cases (social participation). Material and financial exclusion was measured using the question: "Thinking of your household's total monthly income, is your household able to make ends meet?" Answering categories were: 1 . very easily, 2. easily, 3. fairly easily, 4 . with some difficulty, 5. with difficulty, and 6. with great difficulty.

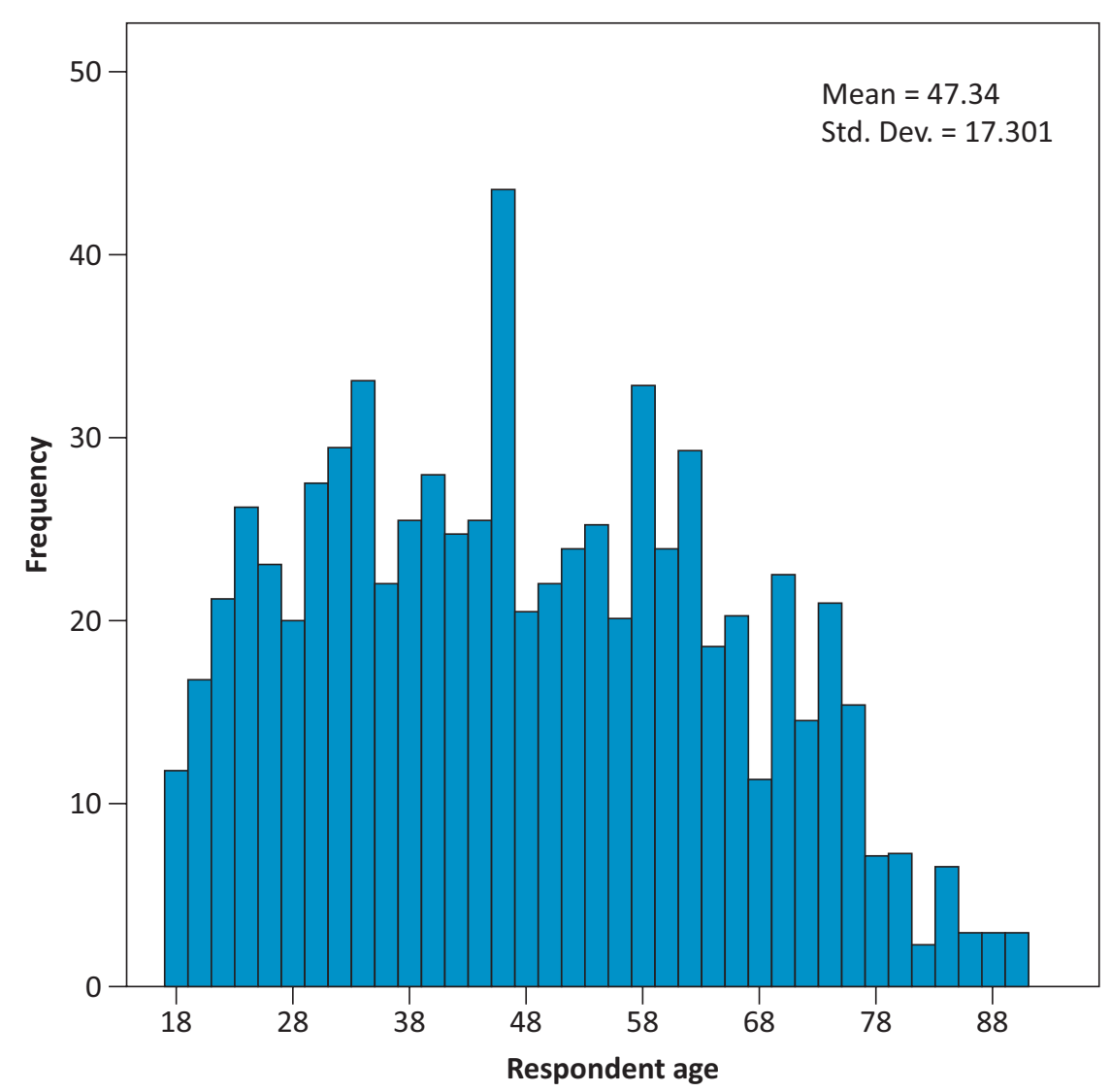

Figure 1. Age distribution. 
Exclusion from social relations was assessed with a factors score based on the following four questions:

1. "On average, how often do you have direct faceto-face contact with any of your family members or relatives living outside the household?"

2. "On average, how often do you have direct face-to-face contact with any of your friends or neighbours?"

3. "On average, how often do you have contact with any of your family members or relatives living outside the household by phone, Internet or by post?"

4. "On average, how often do you have contact with any of your friends or neighbours by phone, Internet or by post?"

The response scale was similar for each of them: 1 . every day or almost every day, 2 . at least once a week, 3 . one to three times a month, 4 . less often, and 5. never. A higher score indicates more exclusion from social relations.

Exclusion from neighbourhood and community is also a factor score computed from six items: "Thinking of physical access, distance, opening hours and the like, how easy or difficult is your access to the following services: (a) banking facilities (e.g., bank branch, ATM), (b) public transport facilities (bus, metro, tram, train, etc.), (c) cinema, theatre, or cultural centre, (d) recreational or green areas, (e) grocery shop or supermarket, (f) recycling services including collection of recyclables". The answer categories were: 1 . very easy, 2. rather easy, 3. rather difficult, and 4. very difficult. A higher score indicates more exclusion from neighbourhood and community.

Exclusion from services is also a factor score computed from five items. Thinking about the last time you needed to see or be treated by a general practitioner (GP), family doctor or health centre, to what extent did any of the following make it difficult to visit a doctor or health care centre? (a) distance to GP/doctor's office/health centre, (b) waiting list, (c) waiting time to see a doctor on the day of the appointment, (d) cost of seeing the doctor, (e) finding time because of work, care for children or for others.

The answer categories are: 1 . not difficult at all, 2. a little difficult, and 3 . very difficult. A higher score indicates more exclusion from services.

\subsection{Confounders}

Urbanity is based on the question "Would you consider the area in which you live to be...", with answering categories: 1 . the open countryside, 2 . a village/small town, 3. a medium to large town, and 4. a city or city suburb. Urbanity was dichotomised into rural (0), including the original categories 1 and 2, and urban (1) including the original categories 3 and 4 . Gender is a dummy variable with 0 for females and 1 for males. For education, two dummy variables were constructed, one represent- ing the International Standard Classification of Education (ISCED) 0-2 levels (lower education) and the other the ISCED 3-4 levels (medium level). The reference category is ISCED 5-8 levels (high education). Rural areas pose special challenges for access to services due to their lack of general service infrastructure, inadequate transport, and depletion of local service and social centres in comparison to urban areas (Walsh, O'Shea, \& Scharf, 2012). Women run higher risks of being socially excluded because they are more often frail, more often widowed, have lower levels of education, have more often disrupted working careers, lower pensions, and less economic resources. Education is related to a number of social exclusion domains. Education and income go hand in hand, and the higher the financial resources the lower the levels of exclusion of most domains (even exclusion from social relations; Scharf et al., 2005).

\subsection{Control Variables}

The following control variables are included in the final analytical model: having children in or outside the respondent's household ( $1=$ yes, $0=$ no), if the respondent has a partner $(1=$ yes, $0=$ no), and if the respondent has chronic diseases $(1=$ yes, $0=$ no).

\subsection{Analytical Approach}

For descriptive reasons, we examine age differences in the study variables. We will conduct independent sample t-tests for the continuous variables (mental wellbeing and social exclusion), and chi-square and adjusted standardised residuals for dummy and categorical variables (all the other variables in the models). The tests will be carried out for both summative and factor scores, if applicable. For informative reasons, we calculate bivariate correlations between dimensions of social exclusion based on summative and factor scores. To examine whether variation in domains of social exclusion explains variation in wellbeing, we employ three linear regression models. With the first model, we examine age differences in mental wellbeing. We control for the potential confounding effect of urbanisation and gender as they correlate with both social exclusion and mental wellbeing. The second model adds the four dimensions of social exclusion to the aforementioned confounders and the age variable. These four dimensions are: material and financial, social relations, neighbourhood, and community and services. If social exclusion moderates the association between age and mental wellbeing, the estimated regression weight of age will become smaller. The third model additionally controls for a number of variables to exclude alternative explanations for an association between age and mental wellbeing, i.e., level of education, partner status, having children, and having chronic diseases. Finally, we will conduct a robustness test by introducing, in addition to the confounding factors, the interactions between social exclusion and age. In this way, we verify 
whether there is a combined role of these factors influencing mental wellbeing. We will run five models, the first four testing one interaction effect at a time, and the final one testing all effects.

\section{Results}

Table 1 presents the basic characteristics of the study sample by age categories and total sample. For variables introduced in the analysis as factor scores, summative scores are included along with the factor scores in order to allow comparisons between age categories. Thirty-five per cent $(\mathrm{N}=259)$ of the sample is 55 years or older, and there are slightly more women than men. Older people have lower mental wellbeing than younger individuals have, and they have higher levels of social exclusion in three dimensions: material and financial re- sources, social relations, and neighbourhood and community $(p<0.05)$. There is variation in the four dimensions of social exclusion, and $27 \%(\mathrm{~N}=196)$ of the sample has a low level of education, $58 \%(N=421)$ a medium level of education and $15 \%(N=109)$ is highly educated. More than two-thirds of the sample has a partner and every one out of five has a chronic disease (one or more). Older individuals have a lower level of education in comparison to the younger, while the presence of the chronic disease is, at $48 \%$, almost ten times higher than among the younger individuals (5\%).

To test our hypotheses, we conducted multiple linear regression analysis. Model 1 (Table 2) evaluates the first hypothesis $(\mathrm{H} 1)$ stating that older Romanians have lower levels of mental wellbeing than younger generations in Romania. The negative effect of age $(B=-0.57)$ indicates that older Romanians score 0.57 points lower

Table 1. Descriptive statistics of the total study sample and by age group..

\begin{tabular}{|c|c|c|c|c|c|c|c|c|}
\hline \multirow[b]{2}{*}{ Variables } & & \multicolumn{2}{|c|}{$\begin{array}{c}18-54 \\
(N=467)\end{array}$} & \multicolumn{2}{|c|}{$\begin{array}{c}55+ \\
(N=259)\end{array}$} & \multicolumn{2}{|c|}{$\begin{array}{l}\text { Total sample } \\
(\mathrm{N}=\mathbf{7 2 6})\end{array}$} & \multirow{2}{*}{$\begin{array}{l}\text { Diff. } \\
p\end{array}$} \\
\hline & & $\mathbf{M}$ & SD & $\mathbf{M}$ & SD & $\mathbf{M}$ & SD & \\
\hline $\begin{array}{l}\text { Mental health } \\
\text { (summative score/ } \\
\text { factor score) }\end{array}$ & & $\begin{array}{c}68 / \\
0.25\end{array}$ & $\begin{array}{l}21 / \\
0.82\end{array}$ & $\begin{array}{l}53 / \\
-0.35\end{array}$ & $\begin{array}{l}25 / \\
0.99\end{array}$ & $\begin{array}{l}63 / \\
0.04\end{array}$ & $\begin{array}{l}23 / \\
0.93\end{array}$ & $p<.001$ \\
\hline $\begin{array}{l}\text { Urbanisation } \\
\text { \% urban }\end{array}$ & & $47 \%$ & & $38 \%$ & & $44 \%$ & & .018 \\
\hline $\begin{array}{l}\text { Gender } \\
\% \text { male }\end{array}$ & & $50 \%$ & & $41 \%$ & & $47 \%$ & & .024 \\
\hline \multirow[t]{4}{*}{$\begin{array}{l}\text { Social exclusion } \\
\text { dimensions }\end{array}$} & $\begin{array}{l}\text { Material and financial } \\
\text { resources* }\end{array}$ & 3.65 & 1.22 & 4.30 & 1.36 & 3.88 & 1.31 & $\mathrm{p}<.001$ \\
\hline & $\begin{array}{l}\text { Social relations } \\
\text { (summative score/ } \\
\text { factor score) }\end{array}$ & $\begin{array}{l}7.64 / \\
-0.15\end{array}$ & $\begin{array}{l}2.83 / \\
0.79\end{array}$ & $\begin{array}{l}8.76 / \\
0.15\end{array}$ & $\begin{array}{l}3.07 / \\
0.87\end{array}$ & $\begin{array}{l}8.04 / \\
-0.04\end{array}$ & $\begin{array}{l}2.97 / \\
0.83\end{array}$ & $\begin{array}{l}p<.001 / \\
p<.001\end{array}$ \\
\hline & $\begin{array}{l}\text { Neighbourhood } \\
\text { and community } \\
\text { (summative score/ } \\
\text { factor score) }\end{array}$ & $\begin{array}{l}12.60 / \\
-0.07\end{array}$ & $\begin{array}{l}4.24 / \\
0.85\end{array}$ & $\begin{array}{l}13.66 / \\
0.16\end{array}$ & $\begin{array}{l}4.75 / \\
0.96\end{array}$ & $\begin{array}{l}12.98 / \\
0.01\end{array}$ & $\begin{array}{l}4.45 / \\
0.90\end{array}$ & $\begin{array}{l}.002 / \\
.001\end{array}$ \\
\hline & $\begin{array}{l}\text { Services } \\
\text { (summative score/ } \\
\text { factor score) }\end{array}$ & $\begin{array}{l}8.13 / \\
0.11\end{array}$ & $\begin{array}{l}2.62 / \\
0.92\end{array}$ & $\begin{array}{l}7.51 / \\
-0.10\end{array}$ & $\begin{array}{l}2.46 / \\
0.86\end{array}$ & $\begin{array}{l}7.91 / \\
0.04\end{array}$ & $\begin{array}{l}2.58 / \\
0.90\end{array}$ & $\begin{array}{l}.001 / \\
.002\end{array}$ \\
\hline Has children & & $66 \%$ & & $76 \%$ & & $69 \%$ & & .005 \\
\hline \multirow[t]{2}{*}{ Education } & $\begin{array}{l}\text { ISCED 0-2 levels } \\
\text { (low education) }\end{array}$ & $18 \%$ & & $42 \%$ & & $27 \%$ & & $\mathrm{p}<.001$ \\
\hline & $\begin{array}{l}\text { ISCED 3-4 levels } \\
\text { (medium education) }\end{array}$ & $62 \%$ & & $51 \%$ & & $58 \%$ & & $\mathrm{p}<.001$ \\
\hline Has partner & & $69 \%$ & & $68 \%$ & & $69 \%$ & & .687 \\
\hline Has chronic disease & & $5 \%$ & & $48 \%$ & & $20 \%$ & & $p<.001$ \\
\hline
\end{tabular}

Notes: ISCED = International Standard Classification of Education; M = Mean; SD = Standard; *Ordinal variable measured on a scale from 1 to 6 . Independent samples t-test show statistically significant differences between the two age categories, 18-54 and 55+, for mental health and the social exclusion dimensions; chi-square and adjusted standardised residuals show statistically significant associations for all the other variables with the exception of the variable has a partner. 
Table 2. Summary of the hierarchical regression analysis for variables predicting mental wellbeing $(N=726)$.

\begin{tabular}{|c|c|c|c|c|c|c|c|c|c|c|}
\hline & & \multicolumn{3}{|c|}{ Model 1} & \multicolumn{3}{|c|}{ Model 2} & \multicolumn{3}{|c|}{ Model 3} \\
\hline & & $B$ & $\beta$ & $S E$ & B & $\beta$ & $S E$ & B & $\beta$ & SE \\
\hline \multicolumn{2}{|l|}{ (Constant) } & 0.09 & & 0.06 & 0.98 & & 0.11 & 1.00 & & 0.13 \\
\hline \multicolumn{2}{|l|}{$\begin{array}{l}\text { Age } 55+ \\
(0 \leq 55,1=55+)\end{array}$} & -0.57 & $-0.29 * *$ & 0.07 & -0.39 & $-0.20 * *$ & 0.07 & -0.30 & $-0.16^{* *}$ & 0.08 \\
\hline \multicolumn{2}{|c|}{$\begin{array}{l}\text { Urbanisation } \\
(0=\text { rural, } 1=\text { urban })\end{array}$} & 0.24 & $0.13 * *$ & 0.07 & 0.12 & $0.06 \#$ & 0.06 & 0.12 & $0.07 \#$ & 0.07 \\
\hline \multicolumn{2}{|c|}{$\begin{array}{l}\text { Gender } \\
(0=\text { female, } 1=\text { male })\end{array}$} & 0.09 & 0.05 & 0.07 & 0.03 & 0.02 & 0.06 & 0.02 & 0.01 & 0.06 \\
\hline \multirow[t]{4}{*}{$\begin{array}{l}\text { Social exclusion } \\
\text { dimensions } \\
\text { (factor scores) }\end{array}$} & $\begin{array}{l}\text { Material and financial } \\
\text { resources }\end{array}$ & & & & -0.23 & $-0.32 * *$ & 0.03 & -0.21 & $-0.30 * *$ & 0.03 \\
\hline & Social relations & & & & -0.15 & $-0.13 * *$ & 0.04 & -0.16 & $-0.14 * *$ & ${ }^{k} 0.04$ \\
\hline & $\begin{array}{l}\text { Neighbourhood } \\
\text { and community }\end{array}$ & & & & -0.11 & $-0.11 * *$ & 0.04 & -0.11 & $-0.10 * *$ & 0.04 \\
\hline & Services & & & & -0.09 & $-0.08 *$ & 0.04 & -0.10 & $-0.10 * *$ & 0.04 \\
\hline \multicolumn{2}{|l|}{$\begin{array}{l}\text { Has children } \\
(1=\text { yes, } 0=\text { no })\end{array}$} & & & & & & & -0.04 & -0.02 & 0.07 \\
\hline \multirow[t]{2}{*}{$\begin{array}{l}\text { Education (ref. } \\
\text { group = high) }\end{array}$} & $\begin{array}{l}\text { ISCED 0-2 levels } \\
\text { (low education) }\end{array}$ & & & & & & & 0.00 & 0.00 & 0.11 \\
\hline & $\begin{array}{l}\text { ISCED 3-4 levels } \\
\text { (medium education) }\end{array}$ & & & & & & & 0.02 & 0.01 & 0.09 \\
\hline \multicolumn{2}{|l|}{$\begin{array}{l}\text { Has partner } \\
(1=\text { yes, } 0=\text { no })\end{array}$} & & & & & & & -0.07 & -0.04 & 0.07 \\
\hline \multicolumn{2}{|c|}{$\begin{array}{l}\text { Has chronic diseases } \\
(1=\text { yes, } 0=\text { no })\end{array}$} & & & & & & & -0.20 & $-0.09 \#$ & 0.09 \\
\hline
\end{tabular}

Notes: SE = Standard Errors; ISCED = International Standard Classification of Education; ${ }^{* *} \mathrm{p}<.01,{ }^{*} \mathrm{p}<.05, \# \mathrm{p}<.10$.

on the mental wellbeing factors score, controlled for the level of urbanisation and gender, which confirms $\mathrm{H} 1$.

Next, Model 2 indicates that all four domains of social exclusion are negatively associated with mental wellbeing (all $p<.01$ ). The lower regression weight for age in Model 2 compared to Model 1 indicates that the lower mental wellbeing of older Romanians can be partly explained by the higher levels of social exclusion. The statistically significant associations between the independent variables age and the four domains of social exclusion, on the one hand, and mental wellbeing on the other cannot be explained by differences with regards to having children or not, level of education, having a partner or not, or having chronic diseases or not (Model 3). Our second hypothesis is also confirmed (see Table 2). The robustness test did not alter our conclusion as none of the interactions between social exclusion and age reached the level of significance. The bivariate correlations between the domains of exclusion (Table 3 ) indicate that domains of exclusion are positively associated. However, associations are modest indicating that the domains cover both shared and unique aspects of social exclusion.

\section{Discussion}

This study has examined whether the level of wellbeing in older Romanians compared to younger Romanians can be understood in terms of a greater likelihood of being socially excluded. Based on a sample of 726 Romanians aged between 18 and 85, of which one-third was 55 years or older, we firstly confirmed that older Romanians have lower levels of mental wellbeing than younger Romanians. Furthermore, we observed that all four domains of social exclusion distinguished in our study were negatively associated with mental wellbeing, and these associations partly explain the lower level of mental wellbeing in older Romanians. Associations between social exclusion and mental wellbeing were independent of the effect of having children, level of education, having a partner, and chronic diseases.

The significant associations between the domains of social exclusion confirmed the multidimensional nature of social exclusion and suggest that people who are excluded from one domain have a higher likelihood to be excluded from another domain. Material and financial re- 
Table 3. Correlation between dimensions of social exclusion (summative scores).

\begin{tabular}{|c|c|c|c|c|c|}
\hline & Age categories & $\begin{array}{c}\text { Material and } \\
\text { financial resources }\end{array}$ & Social relations & $\begin{array}{l}\text { Neighbourhood } \\
\text { and community }\end{array}$ & Services \\
\hline $18-54$ years & Material and financial resources & 1 & $.24 * *$ & $.19 * *$ & $.25 * *$ \\
\hline \multirow{3}{*}{$(N=469)$} & Social relations & $.24 * *$ & 1 & -.03 & .04 \\
\hline & Neighbourhood and community & $.19 * *$ & -.03 & 1 & $.31^{* *}$ \\
\hline & Services & $.25 * *$ & .04 & $.31 * *$ & 1 \\
\hline $55-89$ years & Material and financial resources & 1 & $.25^{* *}$ & $.25^{* *}$ & $.28 * *$ \\
\hline \multirow[t]{3}{*}{$(N=260)$} & Social relations & $.25^{* *}$ & 1 & -.08 & $.17^{* *}$ \\
\hline & Neighbourhood and community & $.25^{* *}$ & -.08 & 1 & $.23 * *$ \\
\hline & Services & $.28^{* *}$ & $.17^{* *}$ & $.23^{* *}$ & 1 \\
\hline
\end{tabular}

Note: ${ }^{* *}$ Correlation is significant at the 0.01 level (2-tailed).

sources are correlated with all other dimensions showing they are key to all other domains. However, the strength of the associations is moderate, indicating that exclusion from one domain does not necessarily imply exclusion from other domains. Social exclusion can take many shapes, and there is no "out" or "in", but a dimension running from not excluded on any domain, to being excluded on all domains. Social exclusion is a complex process, and people may be excluded from a range of different societal institutions and groups, at different levels, and to different degrees (Burchardt, Le Grand, \& Piachaud, 2002; Walker \& Wigfield, 2004). The multidimensional nature of social exclusion requires a holistic and multidimensional approach that goes beyond a mere focus on material resources.

Our research has a number of limitations. One is that the data are cross-sectional, which means that we cannot draw any conclusions with respect to dynamics between social exclusion and mental wellbeing. Being socially excluded may be an antecedent, but it can also be concomitant, or even the outcome of diminished mental wellbeing (Kawachi \& Berkman, 2001). Moreover, we cannot disentangle age from cohort effects. Although we reason that the age differences we found in our study are due to cohort effects, longitudinal data that follow people into old age would provide insight into the plausibility of this conclusion. It may well be that the disadvantaged position of older people is not only the consequence of different life history or growing up under different welfare regimes, it may also be that the difference between older and younger people is the consequence of an accumulation of disadvantages over the life course. Furthermore, we made use of an existing dataset with a limited number of indicators for our social exclusion definition, and with a limited number of older people, which reduced the power of the statistical tests to find significant results. Nevertheless, we observed statistically significant associations between the key variables, and all were in the expected direction. Future studies with a cross-national and longitudinal design are needed to examine the dynamics between social exclusion and mental wellbeing, as well as drawing conclusions with re- spect to the potential modifying effect of the macro social context.

\section{Conclusions}

This study is one of the first to examine the mechanisms behind the lower wellbeing of older Romanians. Much can be learned from examining the correlates of mental wellbeing, in particular the associations between social exclusion and mental wellbeing. We found that social exclusion is a crucial factor in the wellbeing of Romanians, not only older Romanians but also the younger generations, which is in line with the growing evidence. However, older Romanians are disadvantaged on all four domains of social exclusion examined in this study when compared to the younger generations. They are more often excluded from social relations, from material and economic resources, from services, and from facilities in the neighbourhood than younger Romanians. This partly explains why older Romanians have lower mental wellbeing than younger Romanians. Given the already low level of mental wellbeing compared to other European countries, interventions to improve the mental wellbeing of older Romanians are highly needed. One way to achieve this is to increase social inclusion by means of social transfers provided by the government, improving the neighbourhood and access to services, and providing facilities to enhance the social network. While the focus on improving material conditions should remain key, more efforts should be targeted at providing and integrating social and medical services, further developing long term care, while improving older people's access to these services. Policy targeting older people should be more carefully monitored and evaluated with the purpose of improving efficiency and equity as well as ensuring stability and sustainability. In general, policy should stimulate active ageing by changing the emphasis from deficit, decline, disability, and dependency to wellbeing, activity, and independence. More focus is probably also needed at the local level, especially in rural areas, with prominence on community resources, capacity building, healthy ageing, and empowerment in order to increase 
capabilities and enable older people to participate in their communities.

\section{Acknowledgments}

This article is based upon work and funded by COST Action CA15122 ROSEnet, supported by COST (European Cooperation in Science and Technology).

\section{Conflict of Interests}

The authors declare no conflict of interests.

\section{References}

Bălașa, A. (2005). Îmbătrânirea populației: Provocări și răspunsuri ale Europei [Population ageing: Challenges and responses from Europe]. Calitatea Vieții, 16(3/4), 273-288.

Barnes, M., Blom, A., Cox, K., Lessof, C., \& Walker, A. (2006). The social exclusion of older people: Evidence from the first wave of the English Longitudinal Study of Ageing (ELSA): Final report. London: Office of the Deputy Prime Minister, Social Exclusion Unit. Retrieved from https://www.ifs.org.uk/docs/odpm _ social_exclusion.pdf

Bodogai, S. I., \& Cutler, S. J. (2014). Aging in Romania: Research and public policy. The Gerontologist, 54(2), 147-152.

Burchardt, T., Le Grand, J., \& Piachaud, D. (2002). Degrees of exclusion: Developing a dynamic, multidimensional measure. In J. Hills, J. Le Grand, \& D. Piachaud (Eds.), Understanding social exclusion (pp. 30-43). Oxford: Oxford University Press.

Clark, A., D’Ambrosio, C., \& Ghislandi, S. (2015). Poverty profiles and well-being: Panel evidence from Germany. In I. G. Thesia \& K. S. Short (Eds.), Measurement of poverty, deprivation, and economic mobility. Research on Economic Inequality, Volume 23 (pp. 1-22). Washington, DC: Emerald Publishing Ltd.

Craciun, C. (2011). Successful aging: Utopia or the result of lifelong learning? Meaning and representations of ageing in Romanian elderly. Ageing International, 37(4), 373-385. https://doi.org/10.1007/ s12126-011-9131-2

Craciun, C. (2012). Social capital in Romanian old people: Meanings and opportunities for health. Ageing International, 39(2), 106-123. https://doi.org/10.1007/ s12126-012-9157-0

Dahlberg, L., \& McKee, K. (2018). Social exclusion and well-being among older adults in rural and urban areas. Archives of Gerontology and Geriatrics, 79, 176-184. https://doi.org/10.1016/ j.archger.2018.08.007

Dannefer, D. (2003). Cumulative advantage/disadvantage and the life course: Cross-fertilizing age and social science theory. The Journals of Gerontology Series B: Psychological Sciences and Social Sciences,
58(6), S327-S337.

Eurofound. (2016a). European quality of life survey 2016. Data visualisation. Eurofound. Retrieved from www.eurofound.europa.eu/data/european-qualityof-life-survey

Eurofound. (2016b). European quality of life survey 2016: Technical and fieldwork report. Luxembourg: European Foundation for the Improvement of Living and Working Conditions. Retrieved from https://www.eurofound.europa.eu/sites/default/ files/wpef18016.pdf

Eurofound. (2017). European quality of life survey 2016: Quality of life, quality of public services, and quality of society. Luxembourg: Publications Office of the European Union.

European Foundation for the Improvement of Living and Working Conditions. (2018). European quality of life survey integrated data file 2003-2016 (3rd ed.) [data collection]. UK Data Service. Retrieved from https://beta.ukdataservice.ac.uk/datacatalogue/ doi/?id=7348\#!\#3

Eurostat. (2017). The 2018 ageing report. Underlying assumptions and projection methodologies. Luxembourg: Publications Office of the European Union. Retrieved from http://appsso.eurostat.ec.europa.eu/ nui/submitViewTableAction.do

Gîrleanu-Şoitu, D. (2006). Vîrsta a treia [Third age]. Iași: European Institute.

Hellman, J. (1998). Winners take all: The politics of partial reform in postcommunist transitions. World Politics, 50(2), 203-234.

Holt-Lunstad, J., Smith, T. B., Baker, M., Harris, T., \& Stephenson, D. (2015). Loneliness and social isolation as risk factors for mortality: A metaanalytic review. Perspectives on Psychological Science, 10, 227-237. https://doi.org/10.1177/ 1745691614568352

Kawachi, I., \& Berkman, L. F. (2001). Social ties and mental health. Journal of Urban Health, 78(3), 458-467.

Levitas, R., Pantazis, C., Fahmy, E., Gordon, D., Lloyd, E., \& Patsios, D. (2007). The multi-dimensional analysis of social exclusion. Bristol: Townsend Centre for the International Study of Poverty and Bristol Institute for Public Affairs, University of Bristol. Retrieved from https://dera.ioe.ac.uk/6853/1/ multidimensional.pdf

Mackenbach, J. P., Valverde, J. R., Artnik, B., Bopp, M., Brønnum-Hansen, H., Deboosere, P., . . . Nusselder, W. J. (2018). Trends in health inequalities in 27 European countries. Proceedings of the National Academy of Sciences of the United States of America, 115(25), 6440-6445. https://doi.org/10.1073/pnas. 1800028115

Mărginean, I. (Ed.). (2006). Quality of life in Bulgaria and Romania. Luxembourg: Office for the Official Publications of the European Communities.

Mărginean, I. (2015). Interferențe dintre sistemele de pensii şi asistența socială [Interference between the 
systems of pension and social assistance]. In E. Zamfir, S. M. Stănescu, \& D. Arpinte (Eds.), Asistența socială în România după 25 de ani: Răspuns la problemele tranziției [Social assistance in Romania after 25 years: Answers to transition problems] (pp. 577-591). Cluj Napoca: EIKON.

Moulaert, T., Wanka, A., \& Drilling, M. (2017). Mapping the relations between age, space, and exclusion (ROSEnet CA15122 COST ACTION Community and Spatial Working Group Paper). Päivi Topo: ROSEnet. Retrieved from http://rosenetcost.com/ wp-content/uploads/2017/12/community-spatialsynthesis-paper-final.pdf

Neményi, Á. (2011). Demographic ageing in Romania: General and specific consequences on the rural population and the relation to international migration. In A. Hoff (Ed.), Population ageing in Central and Eastern Europe: Societal and policy implications (pp. 149-167). Surrey: Ashgate Publishing Limited.

O’Donnell, P., O'Donovan, D., \& Elmusharaf, K. (2018). Measuring social exclusion in healthcare settings: A scoping review. International Journal for Equity in Health, 17(1). https://doi.org/10.1186/s12939-0180732-1

OECD. (2013). OECD Guidelines on measuring subjective wellbeing. Paris: OECD Publishing. http://dx.doi.org/ 10.1787/9789264191655-en

Ong, A. D., Uchino, B. N., \& Wethington, E. (2016). Loneliness and health in older adults: A mini-review and synthesis. Gerontology, 62(4), 443-449. http://dx. doi.org/10.1159/000441651

Petrescu, C. (2019). Calitatea vieții vârstnicilor [Quality of life in elderly people]. In I. Mărginean \& I. Precupetu (Eds.), Enciclopedia calității vieții [Encyclopedia of quality of life in Romania] (pp. 327-354). București: Editura Academiei Române.

Precupetu, I., \& Pop, C. E. (2016). The role of access to healthcare in self-rated health in Romania, from a European comparative perspective. Sociologie Românească, 14(1), 45-60.

Precupetu, I., \& Precupetu, M. (2014). Romania: High rising inequality over two decades of postcommunist transformation. In B. Nolan, W. Salverda, D. Checchi, I. Marx, A. McKnight, I. G. Tóth, \& H. van de Werfhorst (Eds.), Changing inequalities and societal impacts in rich countries: Thirty countries' experiences (pp. 529-557). Oxford: University Press Oxford.

Price, D. (2006). The poverty of older people in the UK. Journal of Social Work Practice, 20, 251-266. http:// dx.doi.org/10.1080/02650530600931724

Prince, M. J., Harwood, R. H., Blizard, R. A., Thomas, A., \& Mann, A. H. (1997). Social support deficits, loneliness and life events as risk factors for depression in old age: The Gospel Oak project VI. Psychological Medicine, 27(2), 323-332.

Sandu, D. (1999). Spațiul social al tranziției [The social space of transition]. București: Editura Polirom.

Sandu, D. (2009). Lumi sociale de vârstă și rezidență în Uniunea Europeană [Age and residencespecific social worlds in the European Union]. Sociologie Românească, 7(2), 3-26.

Scharf, T., Phillipson, C., \& Smith, A. E. (2005). Social exclusion of older people in deprived urban communities of England. European Journal of Ageing, 2(2), 76-87. http://dx.doi.org/10.1007/s10433-0050025-6

Stolz, E., Mayerl, H., Waxenegger, A., \& Freidl, W. (2017). Explaining the impact of poverty on old-age frailty in Europe: Material, psychosocial and behavioural factors. European Journal of Public Health, 27(6), 1003-1009. http://dx.doi.org/10.1093/eurpub/ckx079

Topp, C. W., Østergaard, D., Søndergaard, S., \& Bech, P. (2015). The WHO-5 well-being index: A systematic review of the literature. Psychotherapy and Psychosomatics, 84(3), 167-176. http://dx.doi.org/10.1159/ 000376585

United Nations University. (2018). Transformative Monitoring for Enhanced Equity (TransMonEE) 1990-2007 [Data set]. Unu-Wider. Retrieved from https://www.wider.unu.edu/database/worldincome-inequality-database-wiid4

Treiman., D. J. (2009). Quantitative data analysis: Doing social research to test ideas. San Francisco, CA: Jossey-Bass.

Walker, A., \& Wigfield, A. (2004). The social inclusion component of social quality. European network of indicators of social quality. Fourth draft. Sheffield: University of Sheffield. Retrieved from https:// www.socialquality.org/wp-content/uploads/ import/2014/10/Social-Inclusion-febr-2004.pdf

Walsh, K., O'Shea, E., \& Scharf, T. (2012). Ageing in changing community contexts: Cross-border perspectives from rural Ireland and Northern Ireland. Journal of Rural Studies, 28(4), 347-357. https://doi.org/ 10.1016/j.jrurstud.2012.01.012

Walsh, K., Scharf, T., \& Keating, N. (2017). Social exclusion of older persons: A scoping review and conceptual framework. European Journal of Ageing, 14(1), 81-98. https://doi.org/10.1007/s10433-016-0398-8

WHO. (2004). Promoting mental health: Concepts, emerging evidence, practice. Geneva: World Health Organization.

World Bank. (2008). Romania poverty monitoring analytical and advisory assistance program: Labor market vulnerabilities in Romania. Report no. 47487-RO. Washington, DC: The World Bank. Retrieved from http://documents.worldbank.org/ curated/en/954241468095642363/pdf/ 474870ESWOROOB10Disclosed0031171091.pdf

World Bank. (2018). From uneven growth to inclusive development. Romania's path to shared prosperity. Washington, DC: International Bank for Reconstruction and Development and The World Bank. Retrieved from http://documents.worldbank.org/ curated/en/954241468095642363/pdf/474870ESW0 RO0B10Disclosed0031171091.pdf 
Zaman, C., \& Stănculescu, M. S. (2007). The social dimension in selected candidate countries in the Balkans: Country report on Romania. Enepri Research Report no 40. Europa. Retrieved from http://ec.europa.eu/ employment_social/social_situation/index_en.htm Zamfir, C. (2007). O analiză critică a tranziției [A critical analysis of transition]. Bucharest: Editura Polirom.

\section{About the Authors}
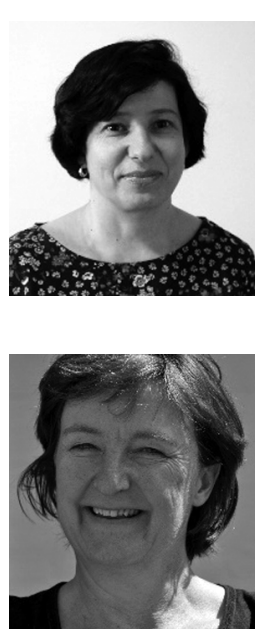

Marja Aartsen is Research Professor at OsloMet-Oslo Metropolitan University, Norway. Her research is on longitudinal developments in older adults' social network, social participation and loneliness in relation to cognitive, physical, and mental health. Her work includes aspects of social exclusion and the role of the local and national context. She is involved in the European research collaboration on social exclusion in older adults (GENPATH), and co-leader of a working group on exclusion from social relations of the COST Action ROSENET.

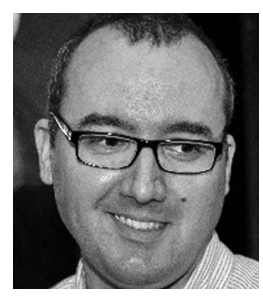

Iuliana Precupetu is a Senior Researcher at the Research Institute for Quality of Life, Romanian Academy. Her research interests are quality of life, social inequality, social exclusion, and health inequalities. Most recently, she co-edited the Encyclopedia of Quality of life in Romania. She is currently involved in a working group on the exclusion of older people from services in the COST Action ROSENET.

Marian Vasile is Associate Professor at the Faculty of Sociology and Social Work, University of Bucharest, and researcher at the Research Institute for Quality of Life, Romanian Academy. His research interests are the effects of social structure and social values on social behaviour, subjective well-being, and mental health. 
COGITATIO

Annex

Table A1. Descriptive statistics of the total study sample and by age group.

\begin{tabular}{|c|c|c|c|c|c|c|c|c|}
\hline \multirow[t]{2}{*}{ Variables } & & \multicolumn{2}{|c|}{$18-54(N=467)$} & \multicolumn{2}{|c|}{$55+(N=259)$} & \multicolumn{2}{|c|}{ Total sample $(\mathrm{N}=726)$} & \multirow{2}{*}{$\begin{array}{l}\text { Diff. } \\
p\end{array}$} \\
\hline & & M & SD & $\mathbf{M}$ & SD & $\mathbf{M}$ & SD & \\
\hline $\begin{array}{l}\text { Mental health } \\
\text { (summative score/factor score) }\end{array}$ & & $68 / 0.25$ & $21 / 0.82$ & $53 /-0.35$ & 25/0.99 & $63 / 0.04$ & $23 / 0.93$ & $\mathrm{p}<.001$ \\
\hline $\begin{array}{l}\text { Urbanisation } \\
(0=\text { rural, } 1=\text { urban })\end{array}$ & & $47 \%$ & & $38 \%$ & & $44 \%$ & & .018 \\
\hline $\begin{array}{l}\text { Gender } \\
(0=\text { female, } 1=\text { male })\end{array}$ & & $50 \%$ & & $41 \%$ & & $47 \%$ & & .024 \\
\hline \multirow[t]{4}{*}{ Social exclusion dimensions } & Material and financial resources* & 3.65 & 1.22 & 4.30 & 1.36 & 3.88 & 1.31 & $p<.001$ \\
\hline & $\begin{array}{l}\text { Social relations } \\
\text { (summative score/factor score) }\end{array}$ & $7.64 /-0.15$ & $2.83 / 0.79$ & $8.76 / 0.15$ & $3.07 / 0.87$ & $8.04 /-0.04$ & $2.97 / 0.83$ & $\mathrm{p}<.001 / \mathrm{p}<.001$ \\
\hline & $\begin{array}{l}\text { Neighbourhood and community } \\
\text { (summative score/factor score) }\end{array}$ & $12.60 /-0.07$ & $4.24 / 0.85$ & $13.66 / 0.16$ & $4.75 / 0.96$ & $12.98 / 0.01$ & $4.45 / 0.90$ & $.002 / .001$ \\
\hline & $\begin{array}{l}\text { Services } \\
\text { (summative score/factor score) }\end{array}$ & $8.13 / 0.11$ & $2.62 / 0.92$ & $7.51 /-0.10$ & $2.46 / 0.86$ & $7.91 / 0.04$ & $2.58 / 0.90$ & $.001 / .002$ \\
\hline $\begin{array}{l}\text { Has children } \\
(1=\text { yes, } 0=\text { no })\end{array}$ & & $66 \%$ & & $76 \%$ & & $69 \%$ & & .005 \\
\hline \multirow[t]{2}{*}{ Education } & $\begin{array}{l}\text { ISCED 0-2 levels } \\
\text { (low education) }\end{array}$ & $18 \%$ & & $42 \%$ & & $27 \%$ & & $\mathrm{p}<.001$ \\
\hline & $\begin{array}{l}\text { ISCED 3-4 levels } \\
\text { (medium education) }\end{array}$ & $62 \%$ & & $51 \%$ & & $58 \%$ & & $p<.001$ \\
\hline $\begin{array}{l}\text { Has partner } \\
(1=\text { yes, } 0=\text { no })\end{array}$ & & $69 \%$ & & $68 \%$ & & $69 \%$ & & .687 \\
\hline Has chronic disease & & $5 \%$ & & $48 \%$ & & $20 \%$ & & $p<.001$ \\
\hline
\end{tabular}

(1= yes, $0=$ no)

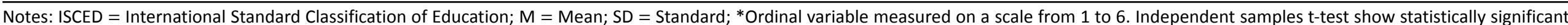

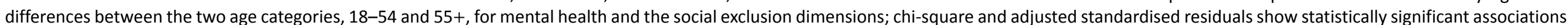
for all the other variables with the exception of the variable has a partner. 
Table A2. Summary of the hierarchical regression analysis for variables predicting mental wellbeing $(\mathrm{N}=726)$.

\begin{tabular}{|c|c|c|c|c|c|c|c|c|c|c|c|c|}
\hline & \multicolumn{4}{|c|}{ Model 1} & \multicolumn{4}{|c|}{ Model 2} & \multicolumn{4}{|c|}{ Model 3} \\
\hline & $B$ & $\beta$ & & $S E$ & $B$ & $\beta$ & & $S E$ & $B$ & $\beta$ & & $S E$ \\
\hline (Constant) & 0.09 & & & 0.06 & 0.98 & & & 0.11 & 1.00 & & & 0.13 \\
\hline Age $55+(0 \leq 55,1=55+)$ & -0.57 & -0.29 & $* *$ & 0.07 & -0.39 & -0.20 & $* *$ & 0.07 & -0.30 & -0.16 & $* *$ & 0.08 \\
\hline Urbanisation $(0=$ rural, $1=$ urban $)$ & 0.24 & 0.13 & $* *$ & 0.07 & 0.12 & 0.06 & \# & 0.06 & 0.12 & 0.07 & \# & 0.07 \\
\hline Gender ( 0 = female, $1=$ male $)$ & 0.09 & 0.05 & & 0.07 & 0.03 & 0.02 & & 0.06 & 0.02 & 0.01 & & 0.06 \\
\hline \multicolumn{13}{|l|}{ Social exclusion dimensions (factor scores) } \\
\hline Material and financial resources & & & & & -0.23 & -0.32 & $* *$ & 0.03 & -0.21 & -0.30 & $* *$ & 0.03 \\
\hline Social relations & & & & & -0.15 & -0.13 & $* *$ & 0.04 & -0.16 & -0.14 & $* *$ & 0.04 \\
\hline Neighbourhood and community & & & & & -0.11 & -0.11 & $* *$ & 0.04 & -0.11 & -0.10 & $* *$ & 0.04 \\
\hline Services & & & & & -0.09 & -0.08 & $*$ & 0.04 & -0.10 & -0.10 & $* *$ & 0.04 \\
\hline Has children $(1=$ yes, $0=$ no $)$ & & & & & & & & & -0.04 & -0.02 & & 0.07 \\
\hline \multicolumn{13}{|l|}{ Education (ref. group = high) } \\
\hline ISCED 0-2 levels (low education) & & & & & & & & & 0.00 & 0.00 & & 0.11 \\
\hline ISCED 3-4 levels (medium education) & & & & & & & & & 0.02 & 0.01 & & 0.09 \\
\hline Has partner $(1=$ yes, $0=$ no $)$ & & & & & & & & & -0.07 & -0.04 & & 0.07 \\
\hline Has chronic diseases $(1=$ yes, $0=$ no $)$ & & & & & & & & & -0.20 & -0.09 & $\#$ & 0.09 \\
\hline
\end{tabular}

Table A3. Correlation between dimensions of social exclusion (summative scores).

\begin{tabular}{|c|c|c|c|c|c|}
\hline \multicolumn{2}{|c|}{ Age categories } & \multirow{2}{*}{$\begin{array}{c}\text { Material and financial resources } \\
1\end{array}$} & \multirow{2}{*}{$\begin{array}{c}\text { Social relations } \\
.24^{* *}\end{array}$} & \multirow{2}{*}{$\begin{array}{c}\text { Neighbourhood and community } \\
.19^{* *}\end{array}$} & \multirow{2}{*}{$\begin{array}{r}\text { Services } \\
.25^{* *}\end{array}$} \\
\hline $18-54$ years $(N=469)$ & Material and financial resources & & & & \\
\hline & Social relations & $.24 * *$ & 1 & -.03 & .04 \\
\hline & Neighbourhood and community & $.19^{* *}$ & -.03 & 1 & $.31 * *$ \\
\hline & Services & $.25^{* *}$ & .04 & $.31 * *$ & 1 \\
\hline \multirow[t]{4}{*}{$55-89$ years $(N=260)$} & Material and financial resources & 1 & $.25^{* *}$ & $.25^{* *}$ & $.28 * *$ \\
\hline & Social relations & $.25 * *$ & 1 & -.08 & $.17^{* *}$ \\
\hline & Neighbourhood and community & $.25^{* *}$ & -.08 & 1 & $.23 * *$ \\
\hline & Services & $.28^{* *}$ & $.17^{* *}$ & $.23 * *$ & 1 \\
\hline
\end{tabular}

Note: ${ }^{* *}$ Correlation is significant at the 0.01 level (2-tailed). 